\title{
Megasphaera paucivorans sp. nov., Megasphaera sueciensis sp. nov. and Pectinatus haikarae sp. nov., isolated from brewery samples, and emended description of the genus Pectinatus
}

\author{
Riikka Juvonen and Maija-Liisa Suihko \\ VTT Biotechnology, PO Box 1500, Espoo, Fl-02044 VTT, Finland
}

Correspondence

Riikka Juvonen

riikka.juvonen@vtt.fi

\begin{abstract}
Seven unidentified strictly anaerobic, Gram-negative, non-spore-forming bacteria from spoiled beer or the brewery environment were characterized. Based on 16S rRNA gene sequence analyses, all strains were affiliated to the Sporomusa sub-branch of the class 'Clostridia'. Three of the strains were non-motile cocci, on average $1.5 \times 1.2 \mu \mathrm{m}$ or $1.2 \times 1.0 \mu \mathrm{m}$, occurring mainly singly or in pairs. They shared nearly identical ( $>99 \%) 16 \mathrm{~S}$ rRNA gene sequences, being most closely related to the species of the Megasphaera-Anaeroglobus group ( $\leqslant 93.9 \%$ similarity). According to DNA-DNA hybridization results, the coccoid strains represented two genospecies, neither of which was related to any of the recognized Megasphaera species. Several phenotypic characteristics and/or DNA G $+C$ content also differentiated the strains from each other and from their closest relatives. The other four novel strains were motile, slightly curved to helical rods, $0 \cdot 6-0 \cdot 8 \times 3-50 \mu \mathrm{m}$ or more in size. They shared identical $16 \mathrm{~S}$ rRNA gene sequences and ribofragment patterns. The highest $16 \mathrm{~S}$ rRNA gene similarity was found between these isolates and Pectinatus cerevisiiphilus ATCC $29359^{\top}(95.6 \%)$ and Pectinatus frisingensis ATCC $33332^{\top}$ (93.6\%). The novel strains also differed from recognized Pectinatus species in their sugar utilization, proteolytic activity, catalase activity, antibiotic resistance and temperature tolerance. The results suggest that the bacteria belong to three novel species, for which the names Megasphaera paucivorans sp. nov. (type strain VTT E-032341 ${ }^{\top}=$ DSM $16981^{\top}$ ), Megasphaera sueciensis sp. nov. (type strain VTT E-97791 ${ }^{\top}=\mathrm{DSM} 17042^{\top}$ ) and Pectinatus haikarae sp. nov. (type strain VTT E-88329 ${ }^{\top}=$ DSM $16980^{\top}$ ) are proposed.
\end{abstract}

The genera Megasphaera and Pectinatus include several beerspoilage bacteria (for a review see Haikara \& Helander, 2002). These Gram-negative, strictly anaerobic bacteria are affiliated to the Sporomusa sub-branch of the class 'Clostridia' in the phylum Firmicutes (Willems \& Collins, 1995; Strömpl et al., 1999; Marchandin et al., 2003). At present, the genus Megasphaera Rogosa 1971 emend. Engelmann and Weiss 1985, emend. Marchandin et al. 2003 comprises three species: the type species Megasphaera elsdenii Rogosa 1971,

Published online ahead of print on 9 December 2005 as DOI 10.1099/ ijs.0.63699-0.

Abbreviations: ML, maximum-likelihood; MP, maximum-parsimony; $\mathrm{NJ}$, neighbour-joining.

The GenBank/EMBL/DDBJ accession numbers for the 16S rRNA gene sequences of strains VTT E-97791 ${ }^{\top}$, VTT E-032341 ${ }^{\top}$, VTT E$88329^{\top}$ and VTT E-90406 ${ }^{\top}$ are DQ223729, DQ223730, DQ223731 and DQ217599, respectively.

Results of ribotyping analysis and volatile fatty acid profiles of the novel strains are available as supplementary material in IJSEM Online. first described as 'Peptostreptococcus elsdenii' (Gutierrez et al., 1959), Megasphaera cerevisiae Engelmann and Weiss 1986 and Megasphaera micronuciformis Marchandin et al. 2003. M. cerevisiae is the only brewery-associated species (Engelmann \& Weiss, 1985; Suihko \& Haikara, 2001). It spoils mainly low-alcohol beers by producing turbidity, $\mathrm{H}_{2} \mathrm{~S}$ and short-chain fatty acids. At the time of writing, the genus Pectinatus Lee et al. 1978 comprises two brewerycontaminating species, Pectinatus cerevisiiphilus Lee et al. 1978 emend. Schleifer et al. 1990 and Pectinatus frisingensis Schleifer et al. 1990. They are common spoilage bacteria of unpasteurized packaged beers. Signs of spoilage include turbidity and off-flavours from the synthesis of organic acids and sulphuric compounds (Haikara \& Helander, 2002). In an earlier study, we characterized 32 Megasphaera and Pectinatus strains of brewery origin, earlier identified by conventional methods, using ribotyping, specific PCR primers and partial 16S rRNA gene sequencing. The results indicated that four of the strains could represent a novel Pectinatus species and one strain could be a new member of the genus Megasphaera (Suihko \& Haikara, 2001). 
Supporting our results, one of the Pectinatus strains, DSM 20764, has also been reported to exhibit low DNA relatedness ( $<20 \%$ DNA-DNA reassociation value) with the previously described Pectinatus species and to contain cadaverine in its cell-wall peptidoglycan (http://www. dsmz.de/strains/no020764.htm), a typical feature for many members of the Sporomusa sub-branch (Schleifer et al., 1990; Strömpl et al., 1999). The aim of the present study was to investigate in further detail the taxonomic affiliation of the atypical brewery-contaminating strains, tentatively identified as Megasphaera and Pectinatus spp., and two novel coccoid-shaped isolates from spoiled beer.

\section{Strains}

Strains VTT E- $032341^{\mathrm{T}}$ and VTT E-042576 originated from a spoiled Italian lager beer $(\mathrm{pH} 4 \cdot 3)$ with an alcohol content of $5 \%(\mathrm{v} / \mathrm{v})$. Strain VTT E-97791 ${ }^{\mathrm{T}}$ was isolated from a spoiled Swedish lager beer $(\mathrm{pH} 4 \cdot 9)$ containing $2 \cdot 8 \%(\mathrm{v} / \mathrm{v})$ alcohol. Strains VTT E- $88329^{\mathrm{T}}$ and VTT E- 88330 originated from air of a brewery bottling hall in Finland and VTT E-89371 from a spoiled Finnish lager beer containing 2.7\% $(\mathrm{v} / \mathrm{v})$ alcohol. The isolates were obtained from the samples by plating on peptone/yeast extract/fructose (PYF) medium (Suihko, 1999) followed by anaerobic incubation at $30^{\circ} \mathrm{C}$. Strain VTT E-97914 (=DSM 20764) was originally isolated from spoiled German beer and it was obtained from the DSMZ. The following reference strains were used: $M$. cerevisiae VTT E-79111 ${ }^{\mathrm{T}}$, M. elsdenii VTT E-84221 ${ }^{\mathrm{T}}$, M. micronuciformis VTT E- $042113^{\mathrm{T}}$ (= AIP $412.00^{\mathrm{T}}$, provided by $\mathrm{H}$. Marchandin, CHU-Montpellier, France), P. frisingensis VTT E- $79100^{\mathrm{T}}$ and P. cerevisiiphilus VTT E-79103 ${ }^{\mathrm{T}}$. The strains were subcultured on PYF or peptone/yeast extract/ glucose (PYG) (for VTT E-97791 ${ }^{\mathrm{T}}$ ) medium (Suihko, 1999) at $30{ }^{\circ} \mathrm{C}$, with the exception of VTT E- $042113^{\mathrm{T}}$, for which MRS agar (Oxoid) with $1 \%$ fructose (BDH) and 25\% fermented wort without hops and an incubation temperature of $37^{\circ} \mathrm{C}$ were used. Anaerobic conditions were created using a Whitley Anaerobic Cabinet MK III (Don Whitley Scientific) with $80 \% \mathrm{~N}_{2}, 10 \% \mathrm{CO}_{2}$ and $10 \% \mathrm{H}_{2}$ or Anoxomat WS8000 (Mart Microbiology) with $85 \% \mathrm{~N}_{2}, 5 \%$ $\mathrm{CO}_{2}$ and $10 \% \mathrm{H}_{2}$.

\section{Morphological characterization}

Cell morphology (including motility) and Gram staining of 1-, 2- and 3-day-old broth cultures were examined by phase-contrast and normal light microscopy, respectively, at 800-1250 $\times$ magnification (Polyvar; Reichert-Jung). Cell size ranges were expressed as mean width and length of 20 cells \pm SD. Colony morphologies were determined after 3-4 and 7 days incubation on PYF or PYG plates. The results of the morphological characterization are presented in Table 1 and in the species descriptions below. The cellular characteristics of VTT E- $97791^{\mathrm{T}}$, VTT E-032341 ${ }^{\mathrm{T}}$ and VTT E-042576 together with their isolation source and beer-spoilage ability suggested that they belong to the genus Megasphaera, which contains Gram-negative, non-motile, strictly anaerobic cocci (Rogosa, 1971; Engelmann \& Weiss, 1985; Marchandin et al.,
2003). Cells of the novel isolates were, however, smaller than those of M. elsdenii or M. cerevisiae and bigger than those of M. micronuciformis (Table 1). Strains VTT E-88329 ${ }^{\mathrm{T}}$, VTT E-88330, VTT E-89371 and VTT E-97914 resembled members of the genus Pectinatus morphologically (Schleifer et al., 1990). They formed an ' $X$ ' shape during movement, which is characteristic for $P$. frisingensis and $P$. cerevisiiphilus (Lee et al., 1978; Haikara et al., 1981) and discriminates them from morphologically similar Selenomonas species (Hespell et al., 1999).

\section{Genetic characterization}

Automated ribotyping (RiboPrinter Microbial Characterization System; DuPont Qualicon) with EcoRI was performed as described by Bruce (1996). The strains were ribotyped until the same pattern was generated three times. For 16S rRNA gene sequencing, DNA was isolated from $0 \cdot 5-1 \mathrm{ml}$ liquid cultures by bead-beating with $200 \mu \mathrm{m}$ glass beads $\left(0 \cdot 1 \mathrm{~g} \mathrm{ml}^{-1}\right.$; Sigma) in a Ribolyser instrument ( $2 \mathrm{~min}$ at $6.5 \mathrm{~m} \mathrm{~s}^{-1}$; Hybaid) after washing of cells in ultra-pure water. Extracts $(2-5 \mu \mathrm{l})$ were used directly as templates in $50 \mu \mathrm{l}$ PCRs. The $16 \mathrm{~S}$ rRNA gene was amplified according to Carlier et al. (2002) except that DyNAzyme II DNA polymerase (Finnzymes) was used. Resulting PCR products were purified using the QIAquick PCR Purification kit (Qiagen) and the manufacturer's procedure. Both strands of the gene were sequenced using the PCR primers and the primers described by Wilmotte et al. (1993) and ABI Prism BigDye Terminator version 3.0 or 3.1 Ready Reaction cycle sequencing kit (Applied Biosystems). Sequencing products were electrophoresed in the ABI Prism 310 Genetic Analyzer (Applied Biosystems). The sequences were compiled with the software DNAMAN version 4.1 (Lynnon BioSoft) and compared to GenBank/EMBL/DDBJ databases using BLAST (Altschul et al., 1997). The 16S rRNA gene sequences were aligned using Fast aligner. Phylogenetic relationships were inferred for representative strains (VTT E-97791 ${ }^{\mathrm{T}}$, VTT E$032341^{\mathrm{T}}$ and VTT E-88329 ${ }^{\mathrm{T}}$ ) using neighbour-joining (NJ; Saitou \& Nei, 1987), maximum-parsimony (MP; Kluge \& Farris, 1969) and maximum-likelihood (ML; Olsen et al., 1994) algorithms in the software package ARB (Strunk et al., 2000). Vertical gaps and ambiguous nucleotides were excluded from the analyses. Evolutionary distances for the $\mathrm{NJ}$ analysis were based on the correction of Jukes \& Cantor (1969). Robustness of the NJ and MP tree topologies was estimated by bootstrapping with 1000 replications. DNADNA hybridization and $\mathrm{G}+\mathrm{C}$ content analysis were done at DSMZ. Cells were disrupted with a French pressure cell (Thermo Spectronic) and purified on hydroxyapatite (Cashion et al., 1977). Hybridization was done according to De Ley et al. (1970) with the modifications of Huß et al. (1983) using a Cary 100 Bio UV/VIS spectrophotometer with in situ temperature probe (Varian). The DNA $\mathrm{G}+\mathrm{C}$ content was determined by HPLC (adapted from Tamaoka \& Komagata, 1984) of P1-nuclease-digested, dephosphorylated DNA (Mesbah et al., 1989) and calculated according to Mesbah et al. (1989). 
Table 1. Differential characteristics of the novel Megasphaera species and closely related Gram-negative, strictly anaerobic cocci

Strains: 1, VTT E-032341 ${ }^{\mathrm{T}}$ and VTT E-042576; 2, VTT E-97791 ${ }^{\mathrm{T}}$; 3, M. micronuciformis VTT E-042113 ${ }^{\mathrm{T}}$; 4, M. cerevisiae VTT E-79111 ${ }^{\mathrm{T}}$; 5, M. elsdenii VTT E-84221 ${ }^{\mathrm{T}}$; 6, A. geminatus AIP $313.00^{\mathrm{T}}$. Data for M. micronuciformis are from Marchandin et al. (2003) except for cell size and utilization of adonitol, dulcitol, DL-erythritol, $\alpha$-D-melibiose, xylitol, succinate and pyruvate. Data for AIP $313.00^{\mathrm{T}}$ are from Carlier et al. (2002). DNA G + C contents of VTT E-79111 ${ }^{\mathrm{T}}$ and VTT E- $84221^{\mathrm{T}}$ are taken from Engelmann \& Weiss (1985) and Rogosa (1971), respectively. +, Positive; - , negative; $\mathrm{W}$, weakly positive; \pm , variable; ND, not determined; $\mathrm{R}$, resistant; s, susceptible. Additional test results: all strains were negative for reduction of nitrate ${ }^{a b \star}$, formation of indole $e^{a b}$, oxidase, catalase ${ }^{a b}$ and urease activities and hydrolysis of aesculin, milk $^{b}$, gelatin ${ }^{b}$ and arginine. All strains were also negative (except those in parentheses) for fermentation of adonitol, D-cellobiose ${ }^{a b}$, dulcitol, DL-erythritol, aesculin ${ }^{a b}$, glycerol ${ }^{a}$, glycogen (AIP $313.00^{\mathrm{T}}$, VTT E-042113 ${ }^{\mathrm{T}}$ ), i-inositol, inulin (AIP $313.00^{\mathrm{T}}$, VTT E-042113 ${ }^{\mathrm{T}}$ ), lactose ${ }^{a b}, \alpha-\mathrm{D}-$

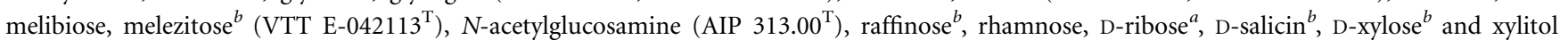
and utilization of succinate ${ }^{a b}$. All strains were positive for utilization of pyruvate ${ }^{a b}$ and susceptible to 1 mg kanamycin and bile discs.

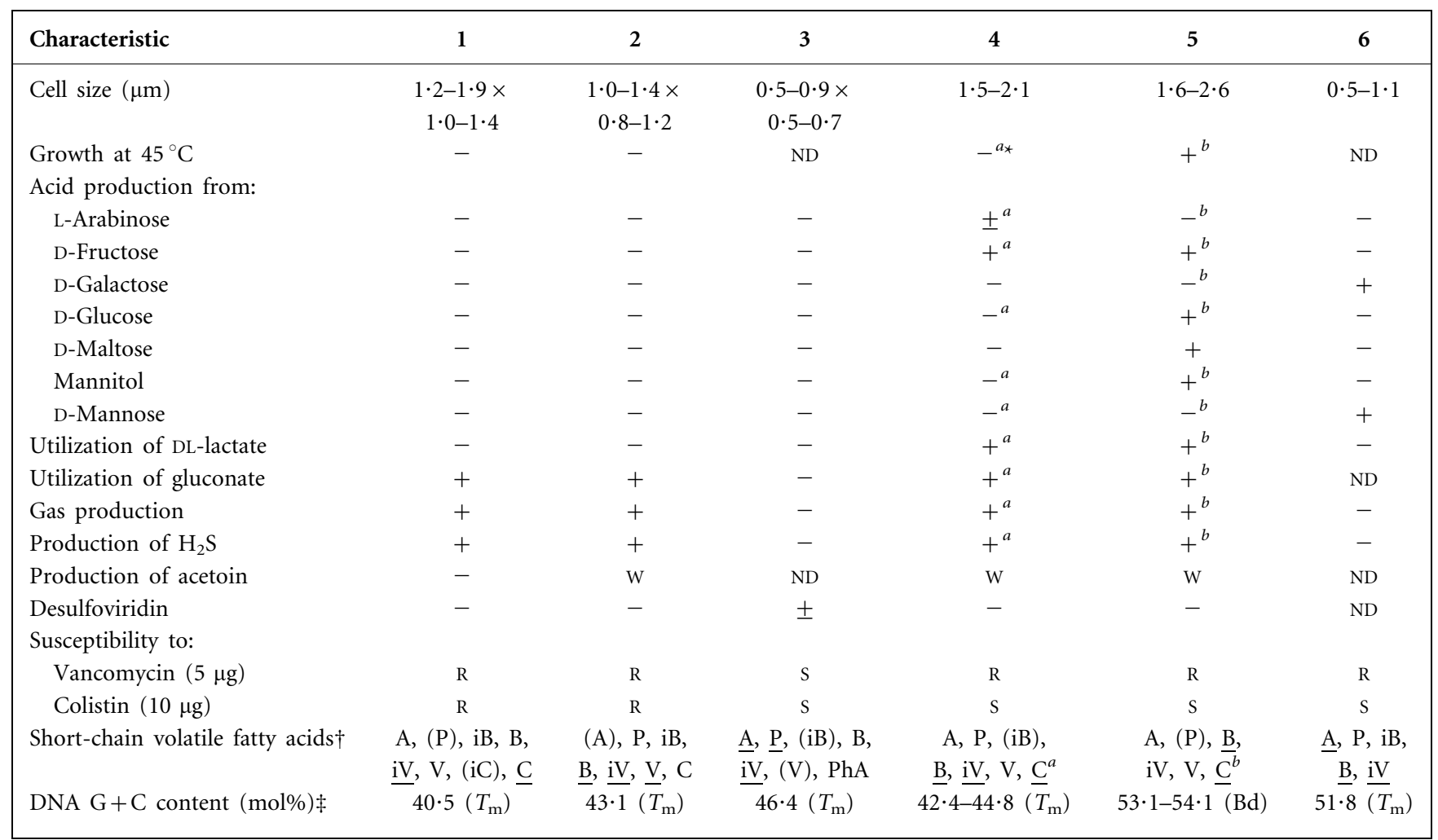

${ }^{\star}$ Test was also performed in the following study with the following strain(s) and gave congruent result: $a$, Engelmann \& Weiss (1985) with VTT E-79111 ${ }^{\mathrm{T}}$ and 11 other strains; $b$, Gutierrez et al. (1959), Rogosa (1971) and/or Engelmann \& Weiss (1985) with VTT E-84221 ${ }^{\mathrm{T}}$.

$\dagger \mathrm{A}$, Acetic acid; B, butyric acid; C, caproic acid; iB, isobutyric acid; iC; isocaproic acid; iV, isovaleric acid; $\mathrm{P}$, propionic acid; PhA, 2-phenylacetic acid; V, valeric acid. Major products are underlined; parentheses indicate inconsistent production.

$\ddagger \mathrm{Bd}$, Buoyant density; $T_{\mathrm{m}}$, thermal denaturation.

Genetic diversity of the novel isolates was studied by ribotyping in comparison with previously described Megasphaera and Pectinatus species. The results are available in Supplementary Figs S1 and S2 in IJSEM Online. The fingerprints distinguished VTT E-97791 ${ }^{\mathrm{T}}$ from VTT E-032341 ${ }^{\mathrm{T}}$ and VTT E-042576 (Supplementary Fig. S1). Strain VTT E- $97791^{\mathrm{T}}$ grouped closely with $M$. cerevisiae, while strains VTT E-032341 ${ }^{\mathrm{T}}$ and VTT E-042576 formed a distinct group with the highest similarity to the former strains and $M$. micronuciformis VTT E-042113 ${ }^{\mathrm{T}}$. The fingerprints of the rod-shaped strains (VTT E-88329 ${ }^{\mathrm{T}}$, VTT E-88330, VTT
E-89371, VTT E-97914) grouped together and were clearly distinct from the fingerprints of recognized Pectinatus species (Supplementary Fig. S2). Hence, ribotyping results suggested that the coccoid and rod-shaped strains could respectively represent two and one novel species within the genera Megasphaera and Pectinatus.

Subsequently, nearly complete $16 \mathrm{~S}$ rRNA gene sequences (1467-1556 nt) of the novel strains were determined except that the sequence of VTT E-97914 was taken from Sakamoto (1997). The 16S rRNA gene of Zymophilus raffinosivorans 
VTT E-90406 ${ }^{\mathrm{T}}$ was also sequenced as it was not available from public databases. The sequences (1540 nt) of VTT E- $032341^{\mathrm{T}}$ and VTT E-042576 shared $100 \%$ similarity with each other and $99 \cdot 3 \%$ similarity with VTT E-97791 ${ }^{\mathrm{T}}$. Similarly, the sequences (1467 nt) of VTT E- $88329^{\mathrm{T}}$, VTT E88330, VTT E-89371 and VTT E-97914 were identical. Based on BLAST searches, VTT E-032341 ${ }^{\mathrm{T}}$ and VTT E-97791 ${ }^{\mathrm{T}}$ shared the highest sequence similarity with $M$. micronuciformis $(95 \cdot 1$ and $94.9 \%$, respectively), $M$. cerevisiae (94.6 and $94.5 \%)$, M. elsdenii $(93 \cdot 2$ and $93 \cdot 3 \%)$ and Anaeroglobus geminatus (93.2 and 93.3\%) over 1359 unambiguous bases. The sequences of the rod-shaped strains were most similar to those of $P$. cerevisiiphilus $(96 \cdot 3 \%)$ and P. frisingensis $(94 \cdot 6 \%)$. Thus, based on 16S rRNA gene sequence comparisons, all novel strains are members of the Sporomusa sub-branch of the class 'Clostridia', which contains low-G $+\mathrm{C}$-content Gram-positive bacteria with Gram-negative cell walls (Willems \& Collins, 1995; Strömpl et al., 1999).

In phylogenetic analyses with the most closely related species, VTT E- $032341^{\mathrm{T}}$ and VTT E- $97791^{\mathrm{T}}$ formed a wellsupported group ( $100 \%$ in the NJ and MP trees) that was linked to M. cerevisiae with good and moderate support, respectively, in the NJ (94\%; Fig. 1) and MP (67\%; not shown) trees. Based on the NJ analysis, the most closely related species to VTT E- $032341^{\mathrm{T}}$ and VTT E- $97791^{\mathrm{T}}$ were M. cerevisiae ( 93.9 and $93.9 \%$, respectively), M. micronuciformis $(93 \cdot 2$ and $93 \cdot 1 \%)$, A. geminatus $(90 \cdot 6$ and $90 \cdot 5 \%)$ and M. elsdenii ( $89 \cdot 8$ and $89 \cdot 8 \%)$. In accordance with Marchandin et al. (2003), the applied treeing methods could not resolve the exact branching order within the Megasphaera-Anaeroglobus group. The representative rodshaped strain VTT E-88329 ${ }^{\mathrm{T}}$ grouped with P. cerevisiiphilus in the NJ (97\%; Fig. 2), MP (57\%; not shown) and ML (not shown) analyses. These strains formed a robust cluster ( $100 \%$ in the NJ and MP analyses) together with $P$. frisingensis and Pectinatus sp. B6. After the NJ analysis (Fig. 2), the sequence similarity of VTT E- $88329^{\mathrm{T}}$ to $P$. cerevisiiphilus ATCC $29359^{\mathrm{T}}$ and $P$. frisingensis ATCC $33332^{\mathrm{T}}$ was 95.6 and $93.6 \%$, respectively. In conclusion, the phylogenetic analyses indicate that the new isolates represent novel species because sequence similarities to the closest relatives were below $97 \%$, the level below which strains are generally assigned to separate species (Stackebrandt \& Goebel, 1994).

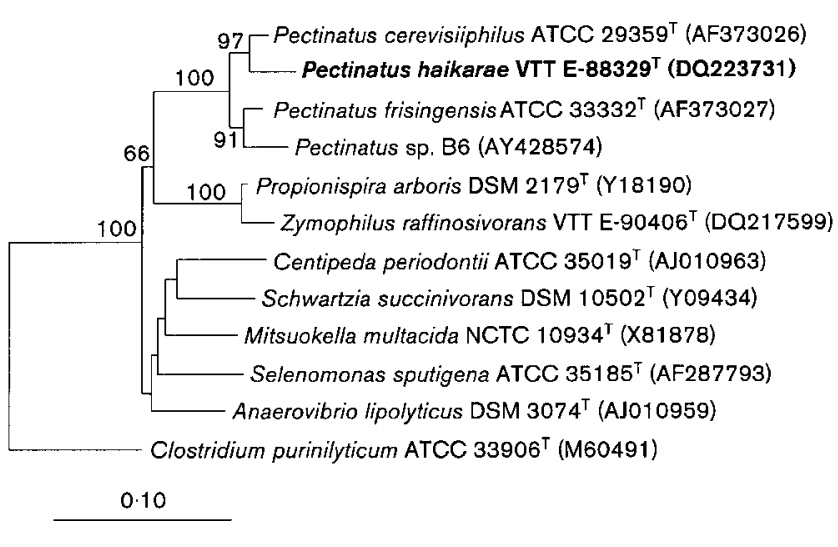

Fig. 2. Consensus neighbour-joining tree of $16 \mathrm{~S}$ rRNA gene sequences (1309 nt) showing the phylogenetic position of the novel rod-shaped strain VTT E-88329 ${ }^{\top}$ within the PectinatusSelenomonas-Sporomusa group. Other details are as in Fig. 1.

The phylogenetic relationships of the coccoid strains to each other and to recognized Megasphaera species were further studied by DNA-DNA hybridization, as it has significantly higher resolving power than 16S rRNA gene sequence analysis (Amann et al., 1992). The results confirmed that VTT E- $97791^{\mathrm{T}}$ and VTT E- $032341^{\mathrm{T}}$ are not related to each other $(41.0 \%)$ or to M. micronuciformis VTT E- $042113^{\mathrm{T}}$ $\left(28.9\right.$ and $17 \cdot 1 \%$, respectively), M. elsdenii VTT E- $84221^{\mathrm{T}}$ $(7 \cdot 2$ and $23 \cdot 6 \%)$ or M. cerevisiae VTT E- $79111^{\mathrm{T}}(22 \cdot 0$ and $3.1 \%)$ at the species level when the recommended criterion of $70 \%$ DNA-DNA relatedness is applied for species delineation (Wayne et al., 1987; Stackebrandt \& Goebel, 1994). The $G+C$ content of the DNA of the proposed type strains of the novel species are shown in Table 1 or in the species descriptions below. The DNA G $+\mathrm{C}$ contents of VTT E- $97791^{\mathrm{T}}$ and VTT E- $88329^{\mathrm{T}}$ fall within the radiations observed for the genera Megasphaera and Pectinatus, respectively (Engelmann \& Weiss, 1985; Schleifer et al., 1990; Marchandin et al., 2003). The DNA G + C content of VTT E- $032341^{\mathrm{T}}$ is somewhat lower than reported for previously known Megasphaera species. The lower DNA $\mathrm{G}+\mathrm{C}$ content clearly distinguishes both VTT E-97791 ${ }^{\mathrm{T}}$ and VTT E- $032341^{\mathrm{T}}$ from the closely related A. geminatus (Carlier et al., 2002).

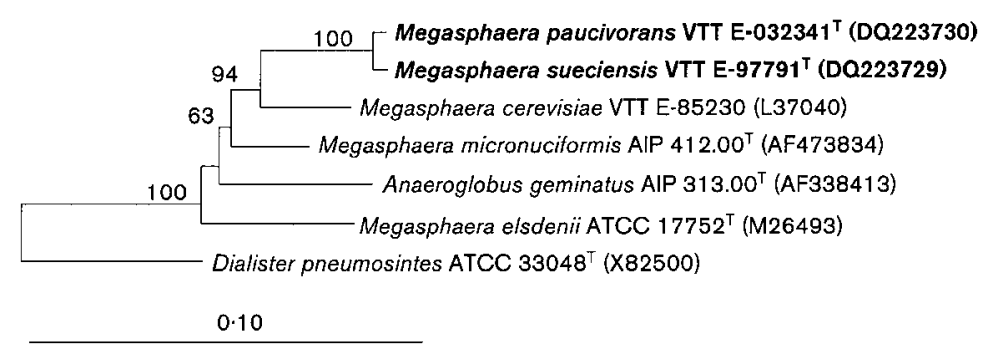

Fig. 1. Consensus neighbour-joining tree of 16S rRNA gene sequences (1309 nt) showing the phylogenetic positions of the novel coccoid strains VTT E-032341 ${ }^{\top}$ and VTT E-97791 within the Megasphaera-Anaeroglobus group. Bootstrap values (expressed as percentages of 1000 replications) greater than $60 \%$ are shown at the branch points. Species names are followed by strain numbers and GenBank accession numbers. Bar, $10 \%$ nucleotide substitutions. 


\section{Biochemical and physiological characterization}

Biochemical and physiological characterization was performed using actively growing cultures, PYF medium and incubation at $30^{\circ} \mathrm{C}$, unless otherwise stated. All media were pre-reduced and all tests included positive and negative control strains. Nitrate reduction, arginine hydrolysis, urease activity, acetoin production and bile resistance were tested using diagnostic tablets and procedures from Rosco A/S. For antibiotic susceptibility tests, An-ident discs (Oxoid) were used. Gas production was determined in autoclaved PYF and PYG broth with inverted Durham tubes. Growth in MRS (Oxoid) and PY (Holdeman et al., 1977) media, in selective SMMP broth for Megasphaera and Pectinatus species (Lee, 1994) and in supplemented brucella blood agar (Jousimies-Somer et al., 2002) was also examined. In addition, the ability of selected strains $\left(5 \times 10^{8}\right.$ cells $)$ to grow in different beers $(330 \mathrm{ml}, 0 \cdot 3-4 \cdot 6 \% \mathrm{v} / \mathrm{v}$ alcohol, $\mathrm{pH} 4 \cdot 1-4 \cdot 5)$ was studied. Aerotolerance was examined by incubating plate cultures for 7 days in atmospheric air, in air with $10 \% \mathrm{CO}_{2}$ (Anoxomat WS8000) and under anaerobic conditions (control). For temperature limits of growth, plate cultures were incubated at $10,15,20,30,37,40$ or $45^{\circ} \mathrm{C}$ and inspected after 7 and 14 days. Other growth tests were performed after Holdeman et al. (1977) or Jousimies-Somer et al. (2002). Short-chain fatty acids produced by the strains were extracted from 5-day-old broth cultures according to Jousimies-Somer et al. (2002). Volatile fatty acids were determined by GC as described by Suihko \& Haikara (2001). Non-volatile acids were analysed by HPLC using the method of Rajakylä (1981) with minor modifications (oven temperature $35^{\circ} \mathrm{C}, 5 \mathrm{mM}$ sulphuric acid as a carrier liquid,

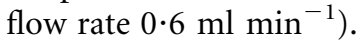

Results of the physiological and biochemical tests are presented in Tables 1 and 2 and in the species descriptions below. None of the strains produced succinic, lactic or pyruvic acids. The volatile fatty acid profiles of the coccoid strains were dominated by C4-C6 acids (Supplementary Table S1 in IJSEM Online), which is characteristic for members of the genus Megasphaera (Engelmann \& Weiss, 1985; Haikara \& Lounatmaa, 1987; Jousimies-Somer et al., 2002; Marchandin et al., 2003), supporting their affiliation to this genus. However, strains VTT E-032341 ${ }^{\mathrm{T}}$ and VTT E-97791 differed from the type strains of recognized Megasphaera species in that they produced isovaleric acid as the major end product. The fatty acid profiles of the type strains of $M$. cerevisiae and M. elsdenii determined in this study are in agreement with the results of Haikara \& Lounatmaa (1987) and Suihko \& Haikara (2001). The metabolic end products of M. micronuciformis VTT E- $042113^{\mathrm{T}}$ were not analysed as it did not grow in PYG or PYF broth. No major differences were found in the volatile fatty acid profiles between the novel rod-shaped strains (VTT E-88329 ${ }^{\mathrm{T}}$, VTT E-88330, VTT E-89371, VTT E-97914) and the type strains of recognized Pectinatus species (Supplementary Table S2 in IJSEM Online). All strains also produced $\mathrm{H}_{2} \mathrm{~S}$ and acetoin, but succinic, lactic and pyruvic acids were not detected. The production of acetate, propionate, $\mathrm{H}_{2} \mathrm{~S}$ and acetoin as
Table 2. Differential characteristics of Pectinatus haikarae sp. nov. and other species of the genus Pectinatus

Strains: 1, VTT E-88329 ${ }^{\mathrm{T}}$, VTT E-88330, VTT E-97914 and VTT E-89371; 2a, P. cerevisiiphilus VTT E-79103 ${ }^{\mathrm{T}} ; 2 \mathrm{~b}$, combined data for 11 P. cerevisiiphilus strains from Haikara et al. (1981) and Schleifer et al. (1990); 3a, P. frisingensis VTT E-79100; 3b, combined data for 14 P. frisingensis strains from Haikara et al. (1981) and Schleifer et al. (1990). Symbols:,$+ 75 \%$ or more of the strains are positive; $\mathrm{W}, 75 \%$ or more of the strains are weakly positive;,$- 75 \%$ or more of the strains are negative;, $\pm 26-74 \%$ of the strains are negative; ND; not determined; $R$, resistant; $S$, susceptible. Additional test results: all strains were positive for acid production from adonitol ${ }^{a b_{\star}} \dagger, \mathrm{L}$-arabinose ${ }^{a b c}$, DL-erythritol ${ }^{a b c d e}, \mathrm{D}-$ fructose $^{a b c d e}, \mathrm{D}$-galactose $\mathrm{e}^{a b c}, \mathrm{D}$-glucose $\mathrm{e}^{a b c d e}$, glycerol $^{a b c d e}$, mannose $^{b}$, rhamnose $^{a b c d e}$, D-ribose ${ }^{a b c d e}$ and utilization of DL-lactate ${ }^{b c e}$. All strains were negative (except those in parentheses) for acid production from glycogen ${ }^{a b c d e}$, inulin ${ }^{a b c e}$, maltose $^{a c}$ (VTT E-97914, VTT E-79100 ${ }^{\mathrm{T}}$, melezitose ${ }^{a b c e}$ and raffinose ${ }^{a b c d e}$, utilization of succinate $\dagger$, production of oxidase $e^{c e}$, desulfoviridin and indole ${ }^{a c d e}$, hydrolysis of arginine and gelatin ${ }^{a c d e}$ and reduction of nitrate ${ }^{c e}$. All strains were susceptible to $1 \mathrm{mg}$ kanamycin and $10 \mu \mathrm{g}$ colistin and bile discs (VTT E-88330).

\begin{tabular}{|c|c|c|c|c|c|}
\hline Characteristic & 1 & $2 a$ & $2 b$ & $3 \mathbf{a}$ & $3 b$ \\
\hline Catalase activity & + & - & - & - & - \\
\hline Susceptibility to $5 \mu \mathrm{g}$ vancomycin & $\mathrm{R}$ & $\mathrm{s}$ & ND & $\mathrm{R}$ & ND \\
\hline Urease activity & - & $+{ }^{b \star}$ & \pm & $-^{a}$ & - \\
\hline Growth at $37^{\circ} \mathrm{C}$ & - & + & + & + & + \\
\hline \multicolumn{6}{|l|}{ Acid production from: } \\
\hline Aesculin & - & $+{ }^{e}$ & - & $+^{c}$ & \pm \\
\hline D-Cellobiose & - & $+{ }^{b e}$ & - & $+^{c}$ & + \\
\hline Dulcitol & + & $+{ }^{d e}$ & \pm & $+{ }^{a c}$ & \pm \\
\hline i-Inositol & + & $-{ }^{b d e}$ & - & $-{ }^{a c}$ & + \\
\hline Lactose & + & $\mathrm{W}$ & - & - & - \\
\hline Mannitol & + & $--^{d e}$ & \pm & $+{ }^{a c}$ & + \\
\hline$\alpha$-D-Melibiose & + & $\mathrm{w}^{d e}$ & + & $-{ }^{a c}$ & - \\
\hline $\mathrm{N}$-Acetylglucosamine & - & $--^{d e}$ & - & $+{ }^{a c}$ & + \\
\hline D-Salicin & - & $--^{d e}$ & + & $-{ }^{a c}$ & + \\
\hline Xylitol & + & $+{ }^{d}$ & - & $+^{c}$ & \pm \\
\hline D-Xylose & + & $\mathrm{w}^{b}$ & + & $\mathrm{w}$ & - \\
\hline \multicolumn{6}{|l|}{ Utilization of: } \\
\hline Gluconate & + & + & \pm & - & \pm \\
\hline Pyruvate & - & - & $\mathrm{ND}$ & + & ND \\
\hline Hydrolysis of milk & + & + & $\mathrm{ND}$ & - & ND \\
\hline
\end{tabular}

*Test was also performed in the following study with the following strain and gave congruent result: $a$, Haikara et al. (1981) with VTT E-79100 ${ }^{\mathrm{T}}$; b, Lee et al. (1978) with VTT E-79103 ${ }^{\mathrm{T}}$; $c$, Schleifer et al. (1990) with VTT E-79100 ${ }^{\mathrm{T}}$; d, Haikara et al. (1981) with VTT E$79103^{\mathrm{T}}$; e, Schleifer et al. (1990) with VTT E-79103 ${ }^{\mathrm{T}}$.

$\dagger$ Test result only available for the novel strains and $P$. frisingensis VTT E-79100 ${ }^{\mathrm{T}}$ and P. cerevisiiphilus VTT E-79103 ${ }^{\mathrm{T}}$.

the major metabolites supports the affiliation of the novel strains to the genus Pectinatus and differentiates them from the closely related Zymophilus raffinosivorans and 
Zymophilus paucivorans, which do not produce acetoin, and Selenomonas lacticifex, which produces large quantities of lactate (Schleifer et al., 1990). The metabolic end products determined for the type strains of $P$. frisingensis and $P$. cerevisiiphilus in this study are in agreement with earlier published data (Lee et al., 1978; Haikara et al., 1981; Haikara, 1989; Schleifer et al., 1990).

\section{Taxonomic considerations}

The results of morphological characterization, 16S rRNA gene sequence comparisons, DNA G $+\mathrm{C}$ content determinations and metabolic end product analyses show that the novel coccoid and rod-shaped strains are respectively members of the genera Megasphaera and Pectinatus. Based on the low degree of DNA relatedness $(<41 \%)$ as measured by DNA-DNA hybridization, the coccoid strains VTT E$97791^{\mathrm{T}}$ and VTT E- $032341^{\mathrm{T}}$ are not related to each other or to the previously known species of the genus Megasphaera at the species level (Wayne et al., 1987). The strains can also be differentiated from each other and from recognized Megasphaera species based on cell size, fermentation of carbohydrates, utilization of organic acids, gas production, antibiotic susceptibility, DNA G + C content (Table 1) and/ or the sequence of the 16S rRNA gene. Furthermore, they can be discriminated from each other by ribotyping with EcoRI. The novel rod-shaped strains (VTT E-88329 ${ }^{\mathrm{T}}$, VTT E-88330, VTT E-89371, VTT E-97914) can be distinguished from the previously described Pectinatus species by ribotyping with EcoRI and by $16 \mathrm{~S}$ rRNA gene sequencing. In addition, the following phenotypic characteristics differentiate them from $P$. frisingensis and P. cerevisiiphilus strains: inability to grow at $37^{\circ} \mathrm{C}$ and ability to hydrolyse milk, positive catalase and negative urease reactions, vancomycin resistance and utilization of different organic acids and carbohydrates (Table 2). Based on these results, we propose two novel Megasphaera species, Megasphaera paucivorans sp. nov. and Megasphaera sueciensis sp. nov., and a novel Pectinatus species, Pectinatus haikarae sp. nov. As the original description of the genus Pectinatus by Lee et al. (1978) does not accommodate all of the phenotypic properties of $P$. haikarae, an emended genus description is proposed.

\section{Description of Megasphaera paucivorans sp. nov.}

Megasphaera paucivorans (pau.ci.vo'rans. L. adj. paucus few, little, L. part. adj. vorans devouring; N.L. part. adj. paucivorans devouring few substrates).

Gram-negative, non-spore-forming and non-motile cocci with a mean size of $1.5 \times 1.2 \mu \mathrm{m}$, mainly arranged in pairs. Stationary phase cells may form chains of 20-25 diplococci and cell clumps. Strictly anaerobic. Moderate to good growth $(2+$ or $3+$ on a scale of 0 to $4+)$ is obtained in autoclaved PYF, PYG, MRS and SMMP media. Growth in SMMP is accompanied by a colour change from violet to yellow. Poor growth in PY medium $(1+)$, but the addition of $1 \%(\mathrm{w} / \mathrm{v})$ pyruvate or gluconate results in heavily turbid suspension $(4+)$. Colonies on PYF plates appear after 3 days at $30^{\circ} \mathrm{C}$ and after 7 days are yellowish, circular, convex, glossy and opaque with entire margins and a diameter of $1-1.5 \mathrm{~mm}$. Grows at $15-37^{\circ} \mathrm{C}$, with an optimum at around $30^{\circ} \mathrm{C}$, but not at 10 or $45^{\circ} \mathrm{C}$. Major volatile fatty acids produced in beer are butyric and isovaleric acids; $\mathrm{H}_{2} \mathrm{~S}$ and minor amounts of propionic, isobutyric, valeric and caproic acids are also produced. Other phenotypic properties and characteristics that differentiate the species from other Megasphaera species are listed in Table 1.

The type strain, VTT E- $032341^{\mathrm{T}}\left(=\mathrm{DSM} 16981^{\mathrm{T}}\right)$, was isolated from spoiled Italian beer.

\section{Description of Megasphaera sueciensis sp. nov.}

Megasphaera sueciensis (sue.ci.en'sis. N.L. fem. adj. sueciensis pertaining to Sweden).

Strictly anaerobic, Gram-negative, non-spore-forming and non-motile cocci, mainly arranged in pairs and occasionally in short chains. Mean cell size is $1 \cdot 2 \times 1 \cdot 0 \mu \mathrm{m}$. Moderate growth $(2+$ on a scale of 0 to $4+)$ is obtained in autoclaved PYF, PYG, MRS and SMMP media at $30^{\circ} \mathrm{C}$. The addition of $1 \%(\mathrm{w} / \mathrm{v})$ pyruvate or gluconate to the PY medium markedly stimulates growth. Colonies on PYF and PYG plates appear after 4 days at $30{ }^{\circ} \mathrm{C}$ and after 7 days are slightly yellowish, glossy, convex, opaque, smooth and circular with entire edges and a diameter of $0.5-0 \cdot 8 \mathrm{~mm}$. Grows at $15-37^{\circ} \mathrm{C}$, with an optimum at around $30^{\circ} \mathrm{C}$, but not at 10 or $45^{\circ} \mathrm{C}$. Other physiological properties and characteristics that differentiate this species from other Megasphaera species are shown in Table 1.

The type strain, VTT E- $97791^{\mathrm{T}}\left(=\mathrm{DSM} 17042^{\mathrm{T}}\right)$, was isolated from spoiled Swedish beer.

\section{Emended description of Pectinatus Lee et al. 1978}

Pectinatus [Pec.ti.na'tus. L. part. adj. pectinatus combed (bacteria)].

Cells are non-spore-forming, slightly curved to helical rods, $0 \cdot 4-0 \cdot 9 \times 2-50 \mu \mathrm{m}$ or more, with rounded ends and a Gram-negative cell wall. They occur singly, in pairs or rarely in short chains. Cells are usually motile by means of comblike flagellation which emanates from only one side of a cell. Cadaverine or putrescine is found in the cell-wall peptidoglycan. Organisms are strictly anaerobic mesophiles with fermentative metabolism. Glucose and fructose are mainly metabolized to acetic and propionic acids. $\mathrm{H}_{2} \mathrm{~S}$ and acetoin and occasionally minor amounts of succinic acid are produced. Cells do not synthesize cytochrome oxidase, desulfoviridin or indole, hydrolyse arginine or gelatin or reduce nitrate. The $\mathrm{G}+\mathrm{C}$ content of the DNA is $38-41 \mathrm{~mol} \%$. The species of the genus can be separated from each other by using various genetic and phenotypic criteria. Isolated from beer and brewing processes. The type species 
is Pectinatus cerevisiiphilus Lee et al. 1978 emend. Schleifer et al. 1990.

\section{Description of Pectinatus haikarae sp. nov.}

Pectinatus haikarae (hai.ka'rae. N.L. gen. fem. n. haikarae of Haikara, named after Dr Auli Haikara for her many contributions to the characterization and detection of Pectinatus species).

Cells are Gram-negative, non-spore-forming, straight or slightly curved, flexible rods with rounded ends, $0 \cdot 6-0 \cdot 8 \times$ $3-50 \mu \mathrm{m}$ or more in size. They usually occur singly and occasionally in pairs. Stationary-phase cells may form long, helical filaments and round and loop-shaped formations or have club-shaped, distended ends. Young cells are motile, following an X-like pattern. Old cells exhibit slow, snake-like movements or are non-motile. Strictly anaerobic. Grows at $15-30^{\circ} \mathrm{C}$, but not at 10 or $37^{\circ} \mathrm{C}$. The optimum lies between 20 and $30^{\circ} \mathrm{C}$. Good growth $(3+$ or $4+$ on a scale of 0 to $4+)$ is obtained in PYF, PYG, MRS and SMMP media after $1-2$ days at $30^{\circ} \mathrm{C}$. Weak growth on supplemented brucella blood agar and PY medium. Colonies on PYF and PYG plates after 3 days at $30^{\circ} \mathrm{C}$ are convex to pyramidal, glossy, opaque, cream to grey in colour and circular with entire margins and a diameter of $0.5-2.5 \mathrm{~mm}$. Major products of fructose fermentation are propionic and acetic acids. Acetoin and $\mathrm{H}_{2} \mathrm{~S}$ are also produced. Differential characteristics compared with other Pectinatus species are shown in Table 2.

The type strain is VTT E- $88329^{\mathrm{T}}\left(=\mathrm{DSM} 16980^{\mathrm{T}}\right)$, with the DNA $\mathrm{G}+\mathrm{C}$ content of $38.8 \mathrm{~mol} \%\left(T_{\mathrm{m}}\right)$, isolated from a brewery bottling hall in Finland. Strains have also been isolated from spoiled German and Finnish beers.

\section{Acknowledgements}

We thank Tarja Nordenstedt for skilful technical assistance, Hannele Virtanen and Helena Simolin for chromatographic analyses and Professor Dr Hans G. Trüper (University of Bonn) for help with the naming of the species. We also thank Dr Maria Saarela for reading of the manuscript. Financial support from the European Commission, Quality of Life and Management of Living Resources Programme, Key Action 1 on Food, Nutrition and Health (contract no. QLK1-CT-200001251) is acknowledged.

\section{References}

Altschul, S. F., Madden, T. L., Schäffer, A. A., Zhang, J., Zhang, Z., Miller, W. \& Lipman, D. J. (1997). Gapped BLAST and PSI-BLAST: a new generation of protein database search programs. Nucleic Acids Res 25, 3389-3402.

Amann, R. I., Lin, C., Key, R., Montgomery, L. \& Stahl, D. A. (1992). Diversity among Fibrobacter strains: towards a phylogenetic classification. Syst Appl Microbiol 15, 23-31.

Bruce, J. (1996). Automated system rapidly identifies and characterizes micro-organisms in food. Food Technol 50, 77-81.

Carlier, J.-P., Marchandin, H., Jumas-Bilak, E., Lorin, V., Henry, C., Carrière, C. \& Jean-Pierre, H. (2002). Anaeroglobus geminatus gen. nov., sp. nov., a novel member of the family Veillonellaceae. Int J Syst Evol Microbiol 52, 983-986.

Cashion, P., Holder-Franklin, M. A., McCully, J. \& Franklin, M. (1977). A rapid method for the base ratio determination of bacterial DNA. Anal Biochem 81, 461-466.

De Ley, J., Cattoir, H. \& Reynaerts, A. (1970). The quantitative measurement of DNA hybridization from renaturation rates. Eur $J$ Biochem 12, 133-142.

Engelmann, U. \& Weiss, N. (1985). Megasphaera cerevisiae sp. nov.: a new gram-negative obligately anaerobic coccus isolated from spoiled beer. Syst Appl Microbiol 6, 287-290.

Gutierrez, J., Davis, R. E., Lindahl, I. L. \& Warwick, E. J. (1959). Bacterial changes in the rumen during the onset of feed-lot bloat of cattle and characteristics of Peptostreptococcus elsdenii n. sp. Appl Microbiol 7, 16-22.

Haikara, A. (1989). Invasion of anaerobic bacteria into pitching yeast. In Proceedings of the European Brewery Convention, 22nd edn, pp. 537-544. New York: Oxford University Press.

Haikara, A. \& Helander, I. (2002). Pectinatus, Megasphaera and Zymophilus. In The Prokaryotes: an Evolving Electronic Database for the Microbiological Community, 3rd edn, release 3.5. Edited by M. Dworkin. New York: Springer.

Haikara, A. \& Lounatmaa, K. (1987). Characterization of Megasphaera sp., a new anaerobic beer spoilage coccus. In Proceedings of the European Brewery Convention, 21st edn, pp. 473-480. New York: Oxford University Press.

Haikara, A., Penttilä, L., Enari, T.-M. \& Lounatmaa, K. (1981). Microbiological, biochemical, and electron microscopic characterization of a Pectinatus strain. Appl Environ Microbiol 41, 511-517.

Hespell, R. B., Paster, B. J. \& Dewhirst, F. E. (1999). The genus Selenomonas. In The Prokaryotes: an Evolving Electronic Database for the Microbiological Community, 3rd edn, release 3.0. Edited by M. Dworkin. New York: Springer.

Holdeman, L. V., Cato, E. P. \& Moore, W. E. C. (1977). Anaerobe Laboratory Manual, 4th edn. Blacksburg, VA: Virginia Polytechnic Institute and State University.

Huß, V. A. R., Festl, H. \& Schleifer, K. H. (1983). Studies on the spectrophotometric determination of DNA hybridization from renaturation rates. Syst Appl Microbiol 4, 184-192.

Jousimies-Somer, H.-R., Summanen, P., Citron, D. M., Baron, E. J., Wexler, H. M. \& Finegold, S. M. (2002). Wadsworth - KTL Anaerobic Bacteriology Manual, 6th edn. Belmont, CA: Star Publishing.

Jukes, T. H. \& Cantor, C. R. (1969). Evolution of protein molecules. In Mammalian Protein Metabolism, pp. 21-132. Edited by H. H. Munro. New York: Academic Press.

Kluge, A. G. \& Farris, F. S. (1969). Quantitative phyletics and the evolution of anurans. Syst Zool 18, 1-32.

Lee, S. Y. (1994). SMMP - a medium for selective isolation of Megasphaera and Pectinatus from the brewery. J Am Soc Brew Chem 52, 115-119.

Lee, S. Y., Mabee, M. S. \& Jangaard, N. O. (1978). Pectinatus, a new genus of the family Bacteroidaceae. Int J Syst Bacteriol 28, 582-594.

Marchandin, H., Jumas-Bilak, E., Gay, B., Teyssier, C., Jean-Pierre, H., Siméon de Buochberg, M., Carrière, C. \& Carlier, J. P. (2003). Phylogenetic analysis of some Sporomusa sub-branch members isolated from human clinical specimens: description of Megasphaera micronuciformis sp. nov. Int J Syst Evol Microbiol 53, 547-553.

Mesbah, M., Premachandran, U. \& Whitman, W. B. (1989). Precise measurement of the $\mathrm{G}+\mathrm{C}$ content of deoxyribonucleic acid by high-performance liquid chromatography. Int J Syst Bacteriol 39, 159-167. 
Olsen, G. J., Matsuda, H., Hagström, R. \& Overbeek, R. (1994). fastDNAml: a tool for construction of phylogenetic trees of DNA sequences using maximum likelihood. Comput Appl Biosci 10, 41-48.

Rajakylä, E. (1981). Separation and determination of some organic acids and their sodium salts by high-performance liquid chromatography. J Chromatogr 218, 695-701.

Rogosa, M. (1971). Transfer of Peptostreptococcus elsdenii Gutierrez et al. to a new genus, Megasphaera [M. elsdenii (Gutierrez et al.) comb. nov.]. Int J Syst Bacteriol 21, 187-189.

Saitou, N. \& Nei, M. (1987). The neighbor-joining method: a new method for reconstructing phylogenetic trees. Mol Biol Evol 4, 406-425.

Sakamoto, K. (1997). Detection of bacterium belonging to the genus Pectinatus. European patent EP0806483 (A1).

Schleifer, K. H., Leuteritz, M., Weiss, N., Ludwig, W., Kirchhof, G. \& Seidel-Rüfer, H. (1990). Taxonomic study of anaerobic, gramnegative, rod-shaped bacteria from breweries: emended description of Pectinatus cerevisiiphilus and description of Pectinatus frisingensis sp. nov., Selenomonas lacticifex sp. nov., Zymophilus raffinosivorans gen. nov., sp. nov., and Zymophilus paucivorans sp. nov. Int J Syst Bacteriol 40, 19-27.

Stackebrandt, E. \& Goebel, B. M. (1994). Taxonomic note: a place for DNA-DNA reassociation and 16S rRNA sequence analysis in the present species definition in bacteriology. Int J Syst Bacteriol 44, 846-849.

Strunk, O., Gross, O. \& Reichel, B. \& 10 other authors (2000). ARB: a software environment for sequence data. Department of
Microbiology, Technische Universität München, Munich, Germany. http://www.arb-home.de

Strömpl, C., Tindall, B. J., Jarvis, G. N., Lünsdorf, H., Moore, E. R. B. \& Hippe, H. (1999). A re-evaluation of the genus Anaerovibrio, with the reclassification of Anaerovibrio glycerini as Anaerosinus glycerini gen. nov., comb. nov. and Anaerovibrio burkinabensis as Anaeroarcus burkinensis [corrig.] gen. nov., comb. nov. Int J Syst Bacteriol 49, 1861-1872.

Suihko, M.-L. (1999). VTT Culture Collection. Catalogue of Strains, 4th edn. Espoo, Finland: Libella Painopalvelu Oy.

Suihko, M.-L. \& Haikara, A. (2001). Characterization of Pectinatus and Megasphaera strains by automated ribotyping. J Inst Brew 107, 175-184.

Tamaoka, J. \& Komagata, K. (1984). Determination of DNA base composition by reversed-phase high-performance liquid chromatography. FEMS Microbiol Lett 25, 125-128.

Wayne, L. G., Brenner, D. J., Colwell, R. R. \& 9 other authors (1987). Report of the ad hoc committee on reconciliation of approaches to bacterial systematics. Int J Syst Bacteriol 37, 463-464.

Willems, A. \& Collins, M. D. (1995). Phylogenetic placement of Dialister pneumosintes (formerly Bacteroides pneumosintes) within the Sporomusa subbranch of the Clostridium subphylum of the grampositive bacteria. Int J Syst Bacteriol 45, 403-405.

Wilmotte, A., Van der Auwera, G. \& De Wachter, R. (1993). Structure of the 16S ribosomal RNA of the thermophilic cyanobacterium Chlorogloeopsis HTF ('Mastigocladus laminosus HTF') strain PCC7518, and phylogenetic analysis. FEBS Lett 317, 96-100. 